\title{
Luba-Kasai Language
}

National Cancer Institute

\section{Source}

National Cancer Institute. Luba-Kasai Language. NCI Thesaurus. Code C154007.

A Niger-Congo Bantu language that is spoken in Central Africa and is an official language of the Democratic Republic of the Congo. 